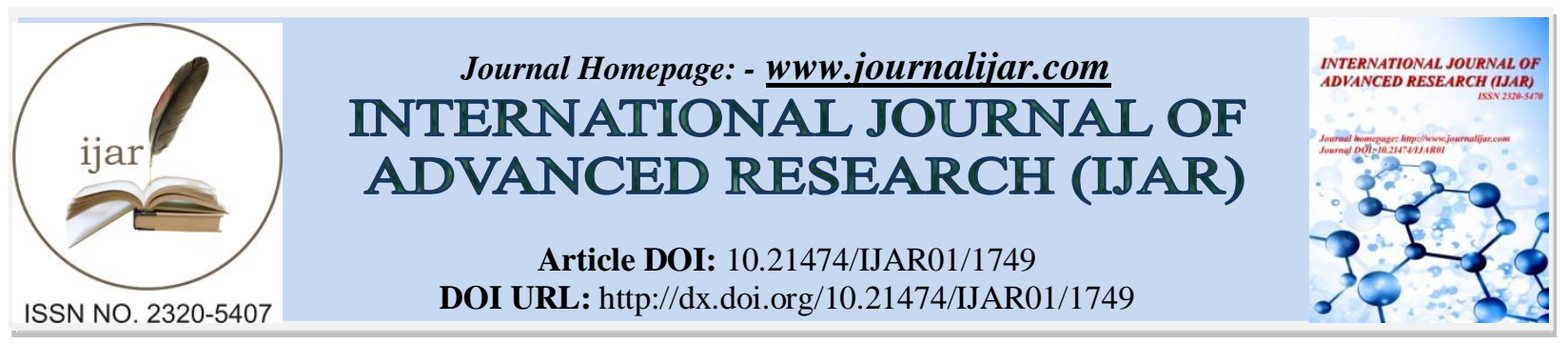

RESEARCH ARTICLE

\title{
COMPARATIVE ANALYZE INSTITUTION OF INQUIRY IN ASIAN COUNTRIES.
}

Fayziev Shokhrud Farmonovich.

$\mathrm{PhD}$, Associate Professor, senior science researcher at Tashkent State University of Law.

\section{Manuscript Info}

Manuscript History

Received: 12 July 2016

Final Accepted: 13 August 2016

Published: September 2016

Key words:-

Criminal procedure, criminal case, the

inquiry, the investigator, the pre-trial

stages, simplified production

\section{Abstract}

In this article, based on a critical analysis of the existing order of inquiry and scrutiny of foreign experience of Asian countries (The Islamic Republic of Iran, Saudi Arabia, Indonesia, Malaysia, Singapore, Japan, Korea, China) put forward constructive suggestions to improve the procedural position of the investigator and the institution of the inquiry as a whole.

The China Criminal procedure code (CPC) based on the principles of socialist legality. The relationship of Criminal Procedure was adopted in 1996, the new Penal Procedure (1979 CPC is radically different) regulation. Section 9 of this Code consists of 225 articles 1 .

In pre trial stage, the public security authorities are given greater powers. CPC of China in accordance with Article 3 the public security authorities to investigate, arrest, arrest and criminal cases assigned to the initial functions

Public safety agencies - the Internal Affairs bodies of the Chinese analog of the vast majority of criminal cases related to management that these bodies. In jurisdiction consist of the Public Prosecutor's Office investigators only heavy and hard crimes.

There is a stage of criminal proceedings, such as in China and Uzbekistan ${ }^{2}$, it is a criminal offense was the fact that early detection of persons suspected of committing a crime or is preparing to send the investigation.

China institute of criminal proceedings stage in our understanding of pre-investigation, criminal proceedings and decisions to reject it, and other procedural steps.

Chinese court control of until investigation the court proceeding does not exist. All serious procedural and investigative actions on the basis of the prosecutor's sanction. At the same indictment as the stage until the preliminary investigation is completed, the confirmation of the indictment is carried out from time to time,

\footnotetext{
${ }^{1}$ www.asia-business.ru/law/law1/criminal.

${ }^{2}$ Part 2 of the Code of Criminal Procedure in China, it was called, and his criminal case, which covers the stages of the investigation and indictment.
}

Corresponding Author:- Fayziev Shokhrud Farmonovich.

Address:- PhD, Associate Professor, Senior science researcher at Tashkent State University of Law. 
This structure of criminal procedure "prosecutorial investigation" is similarity the German model. This stage, the prosecutor or the accused, the court case, or it is not sufficient grounds to reject the indictment.

China-court stage of the criminal proceedings, there are forms of inquiry and preliminary investigation, both the function in a hand of a one body. In our opinion investigation in China understand the options that work was preceding on the public security organs criminal suspect guilty or not guilty of the offense is important or less important that the search and investigative actions aimed at collecting evidence.

Chinese CPC provided for the duration of the investigation. This was certainly the case during office increases the risk of serious harm to the right person. A critical condition, after an investigation that it is this public security authority's preliminary investigation. That is, the list of national legislative bodies of inquiry, the work they undertake the appropriate proceedings and preliminary investigation procedure provided for in the legislation of the mechanism of China.

The main goal of the preliminary investigation evidences collected during the investigation. That is provided for in the Criminal Proceedings of the Republic of Uzbekistan is distributed as lines of evidence to prove each element of the process of China: to gather evidence in the investigation stage, the investigative stage of the investigation, the court stage of the evaluation.

The concept of the national office of the criminal case is a different approach, in our view, these structural and systemic seem to have sided with the functions of the bodies, and proceeding to the procedure in terms of unreasonable charges in accordance with the concentration of powers and procedural implementation.

In general, China is not given enough attention to the issue of the terms of procedural law. Here are the preliminary investigation will also be clearly defined, linked to the term of the person in custody. In other words, the suspect in custody for 2 months, this period can be extended up to 1 month with the permission of the prosecutor's office. Completion of the inquest and preliminary investigation that stems from this period.

The Republic of Korea until the court case on the words of this state in the form of criminal proceedings should continue. Korea's criminal procedure law in Germany and the United States due to formation of the influence of the office's criminal dispute and accused the form of a mixture models. South Korea's main source of criminal procedure in 1954. The Criminal Procedure Code (Article 493) ${ }^{3}$.

Until the court proceedings of the inquiry and the investigation is carried out. Although not provided for in these types of activities have been systematically in CPC. "The Investigation" (184, 194-2) and "inquiry" (78, 164, 176, 299 ) is described in terms of their act as an independent institution.

The inquiry carried out by the police in Korea, during the investigation of the detention, interrogation, examination of such procedural and investigative actions conducted with the permission of the prosecutor. All these procedural actions by the inquiry procedure should be carried out with strict adherence to the form.

It should be noted that the Korean stage of the investigation that the impact of the US legal system sizes evidence of arrest, seizure, bail hearings open to the public only on the basis of a court warrant will be carried out.

Another important aspect of police work within the court system. The arrest of any person brought to court by the police. But at the same time, the Korean spirit of the German legal system, the effect of the criminal proceedings in all criminal proceedings in terms of prosecution agencies carrying out activities carried out under the supervision of the prosecutor. In other words, the security of the person by the court, a warrant procedural measures to restrict the initiative to apply them the prosecution case, due to the prosecutor's office.

CPC of Chinese and Korea are different. Inquiry and preliminary investigation in the criminal procedure allocated as special forms provided. In other words, the national legislation in this regard in China CPC nearer. But compared to China and Korea CPC respect for the dignity of the person and the requirements of procedural forms in harmony

${ }^{3}$ Criminal procedure act republic of Korea Amended by Act No. $\quad$ 705, Sep. 1,1961 
with the norms of the Criminal Procedure Law of the Republic of Uzbekistan. In particular, Korea CPC Article 198 of the inquiry, the investigator, the prosecutor and the requirements of Article 88 of the CPC with the rules on the protection of the rights and freedoms of citizens is almost the same.

In general, the proceedings of the Republic of Korea, the United States and Germany, although the effect of the legal system of this country are superior approach to the prosecution of the criminal proceedings. This is the practice of the court verdict of extremely low $(0.5 \%)$.

The Korea criminal procedure is a specific. At first glance, Korea, the US legal system, the judicial system may appear to blindly perhaps. But the actual situation is not the case. Korean legal system of material and procedural rights, the rule of law. That is, the justice process more important than the result, in particular, ensure the strict observance of the rules and legal procedures just in front of the second issue, which is usually narrow and formal interpretation of the law, proceedings in criminal cases to withdraw, and the pursuit of social justice.

Japan, before speaking about the criminal proceedings on the basis of the formation of the legal system in this country a little bit forward. Interestingly, in Japan in the early 19th century legal system relied solely on the values of Western Europe in the creation of criminal procedure. In particular, Japan's first CPC was adopted in 1880, provides a classic view of the preliminary investigation based on the French model. Japan's second CPC was adopted in 1922, the influence of the German model of criminal proceedings. Japanese court proceedings until the investigation were envisaged in the German case. According to him, occupies a central role in the management entities within the criminal prosecutor, police prosecutor's office support functions. Judicial police officers were the subject of the investigation.

After the Second World War in 1948, Japan received its third CPC the law based on the model of the criminal proceedings of USA. In Japan, the Criminal Procedure Act applies to the present day. The basis of the current trial model based on Anglo-Saxon, it should be noted, that the Japanese management of the preliminary investigation of the criminal case is not in accordance with the shape of the continental completely.

In Japan CPC "Investigation" (investigation), including the term of inquiry and preliminary investigation. Japan-trial investigation and analysis of the articles 189-246 of the preliminary investigation has shown that there is an inquiry or investigation agency structured more consistent regulatory proceedings ${ }^{4}$.

The preliminary investigation carried out by the police, the police hold a suspect for 48 hours, if the suspicion is not confirmed, the release or the materials submitted by the prosecutor, the prosecutor, in turn, the release of the detainee within 24 hours of the application of the measure in court and he was sentenced to decide to apply for a warrant. Taking such a course of CPC detention and prison custody is very similar. If a person sentenced to that punishment imposed, the court decision is valid for 10 days, after 10 days in detention could be extended. That the prosecutor within 20 days to decide whether or not charges against the detained person, in its decision, "the prosecutor discretion" (the principle of conformity with the goal). At the same time, by the guilt of the suspect extremely important, particularly in this release and other obligatory condition for the use of alternative procedural measures. In addition, the public prosecutor before being detained during the investigation allowed, which is a basis for their guilt. But it should be noted that such coerced into signing a confession Saxon system of "guilt by confession agreement" does not appear.

The criminal investigation process is based on the interaction between the police and the prosecutor ${ }^{5}$. At the same time the prosecutor is competent to carry out the investigation itself, which performs the function of a police officer to help him.

In Japan, the criminal court process designed to explore the stages of many scientific studies ${ }^{6}$. Uzbekistan and Japan's special investigations, however, only a comparative analysis by the author ${ }^{7}$.

\footnotetext{
${ }^{4}$ The code of criminal procedure law. no.131. July 10, 1948

${ }^{5}$ Hiroshi Oda Japanese law second edition. 2001. 460-p. 424-425

${ }^{6}$ Kuk Cho, the Japanese "Prosecutorial Justice" and Its Limited Exclusionary Rule, 12 Colum. J. Asian L. 39, 54 (1998). H.Itakura. Gendaykey handzay the keyho-but ronten (Contemporary forms of crime and discussion points of criminal law). Tokyo, 1990, B7; S.Sugivara. Kësey sisetsu car-but shakai fukki (Return to the community from prison). - Keiji seysaku TTE Conn mono DES (That criminal policy). Tokyo, 1991, B.384; Steven C. Teyman,
} 
In general, the Japanese court case in the West, formed the basis of the criminal proceedings, the current Japanese law in continental law system, Saxon legal system is not, namely the complex structure of the Japanese court proceedings until the recognition of the observed elements of Saxon and continental models.

Indonesia, Malaysia and Singapore state criminal office is very similar, and their related specific aspects of a comparison purpose.

Malaysia and Singapore the British formed the basis of the model of the criminal proceedings in these countries, "habeas corpus" institution. A person suspected of having committed a crime within 24 hours of detention in Malaysia, Singapore, the court within 48 hours and shall not be valid or baseless restriction of the freedom of issues fixed. However, unlike Singapore, Malaysia, the national security work almost does not apply the principles of criminal proceedings. "The Internal Security Law" (1960 y.), According to the internal affairs of any person suspected of involvement in anti-state activities be stored for 2 years in prison by the authorities, and this period can be extended for another 2 years. As well as "dangerous drugs" On the Law (1985). Ministry of Internal Affairs to the court stage of a court order and without formal charge 39 suspects remains on hold.

Singapore is a very democratic principle of criminal proceedings, however, there is also the "internal security", "drug abuse," according to the laws of the inquiry body, the police allowed the suspect was arrested and negative, such as 2 years in prison experience is still in force. Interestingly, this period of 39 days in Malaysia, seem very democratic to keep Singapore time limit may be extended by the Minister of Internal Affairs, and that a decision on the appeal is not allowed. But such a procedure is not used in practice, almost by the Prime Minister. Singapore law, the fight against violent crime was a big success with Greece.

Indonesia, Malaysia and Singapore is a relatively new approach in this regard. Indonesia CPC (1981 y.), According to the decision of the court within 24 hours of arrest, and the charge should be. The functions of the criminal proceeding authorized entities differential distribution, inquiry and investigation function of the police, entrusted with the function of the court to support the charges, the prosecutor's office. But at the same time, the Indonesian Criminal Procedure Code (provocation, treason) offenses under the laws unconstitutional norms of criminal prosecution to investigate specific methods, provides for an exception.

When speaking about the Muslim countries, criminal proceedings, based on the rules of Sharia, the religious nature of the origin of the criminal procedural system, which countries should be considered.

Saudi Arabia, the state is completely in accordance with the laws of the Sharia can say that the state of criminal proceedings. Saudi Arabia is a special law on criminal proceedings (2001). Islamic law rules of modern management in the field of criminal law enshrined in harmony with international standards. In particular, in accordance with the guarantees of the presumption of innocence.

In general, the Saudi criminal proceedings are very up-to-date: The preliminary investigation "Investigation Bureau" At the end of the investigation conducted by the "indictment" of "providing public interests," the prosecutor's office approved by the court. In such case the western criminal procedural system which is influenced by the American model, the design of "comparative legal sample" can be considered. The right of a Muslim point of view of the criminal procedural and technical aspects of criminal proceedings in Saudi Arabia this year. One of the peculiarities of the court proceedings, which is in the process of inquiry and investigation procedure does not apply to judicial supervision and investigation is carried out on the basis of the consent of the prosecutor. But this is not the sign of a kind of model Muslim. A number of non-Muslim countries are still carried out under the supervision of the preliminary inquiry and the prosecutor (China, Belarus and etc.).

summary proceedings or an agreed statement of guilt? Analysis of the Draft Law of the Republic of Kazakhstan "On amendments and additions to the Criminal Procedure Code of the Republic of Kazakhstan on simplified pre-trial proceedings" http://www.zakon.kz/158025-uproshhennoe-proizvodstvo-ili.html\#_ftn19

Sh. F. Fayziev Comparative analyze of criminal procedural law of Uzbekistan and Japan (In case of inquiry procedure of Uzbekistan). // Materials of the XXI international scientific and practical conference, «Conduct of modern science», -2015. Volume 9. Law.Philosophy. Sheffield. Science and education LTD. 22-25 pages. 
The process of the Islamic Republic of Iran, it is difficult to say that it is completely based on the right of a Muslim. As a result of the Islamic Revolution in Iran in 1979, the prosecutor's office and the courts of general jurisdiction was abolished, replaced by revolutionary tribunals are introduced, and the new Iranian government to protect religious principles. But 1982 was observed in the values of Western Criminal Procedure partially restored, and now the courts of general jurisdiction applies to the case of two parallel judicial system in Iran. In particular, the courts of general jurisdiction in crimes, crimes against Islam revolutionary tribunals, will be considered political crimes. In 1999, Iran's new CPC. According to him, the 3 types of crimes will be differential: 1) penalty Islamic law (Sharia) is determined on the basis of crimes; 2) crimes against public interests and social order; 3) crimes against the rights of the individual and corporations. Also, this is not the right of a Muslim code of criminal prosecution, the right to more secular forms of: public, private and public procedures; the criminal case as a civil suit; investigation conducted by the judicial police; the investigative judge of the criminal preceding the existence of an entity, such as Iranian continental criminal procedure based on evidence. But, of course, Iran is also the peculiarities of the criminal justice process. For example, the Iranian court to conduct preliminary investigation proceedings of the powers delegated to the chairman of the court. They will carry out the investigation themselves, or the investigating judges can submit. Formal prosecution function rests with the court. Therefore, in 2002, was restored at the prosecutor's bodies are subject to the judicial system: the issue of the appointment and dismissal of the prosecutor must be resolved by the judicial authorities. Criminal technical point of view, Iran-court stage belongs to the continental model. We can say that the stage of preliminary inquiry and trial in Iran to the level of absolute control.

In general, Asian countries, including in some Muslim countries, the criminal justice process analysis shows that, in almost all non-Western forms of criminal proceedings, national, historical, ideological or religious characteristics of the nucleus of Europe, regardless of the criminal procedure, based on the equipment. Even the elements of such a universal form of criminal procedure standards from the European approach any "true" Muslim countries that follow the criminal proceedings is also observed (Saudi Arabia and Iran). 